\title{
TREM2 Gene
}

National Cancer Institute

\section{Source}

National Cancer Institute. TREM2 Gene. NCI Thesaurus. Code C125468.

This gene plays a role in the activation of immune responses. 